\title{
REVIEW
}

\section{Pharmacological aspects of cognitive impairment: past, present and future of drugs in dementia}

\author{
Kathleen Isensee $^{1}$, Georg Petroianu ${ }^{2}$, Holger Stark ${ }^{1}$ \\ ${ }^{1}$ Johann Wolfgang Goethe-Universität, Institut für Pharmazeutische Chemie, ZAFES/CMP, Frankfurt/Main, \\ Germany \\ ${ }^{2}$ United Arab Emirates University, Faculty of Medicine and Health Sciences, Department of Pharmacology and \\ Therapeutics, P.O. Box 17666, Al-Ain, United Arab Emirates
}

Received $24^{\text {th }}$ April 2007.

Revised 26 ${ }^{\text {th }}$ April 2007.

Published online $18^{\text {th }}$ May 2007.

\begin{abstract}
Summary
Cognitive impairment is a dramatically increasing problem affecting many individuals as well as the health system. As we have no causal treatment for the loss of memory, symptomatic treatment is needed. Influencing the ACh system is a generally accepted approach, although other therapeutic treatments are in various stages of development. The multiple target drug approach using hybrid compounds may be another optimized move forward for the treatment of cognitive disorders. Since the complex neuronal regulation is slowly being decoded, there is hope that ways will be found to stop neuronal loss and to generate new synapses.

Keywords: cholin esterase inhibitors - NMDA - receptor antagonist - histaminergic neurotransmission - $\beta$-amyloid peptide - $\tau$-protein - therapy - animal models $-\mathrm{H}_{3}$ receptor - histamine $\mathrm{H}_{3}$
\end{abstract}

\section{INTRODUCTION}

Dementia is a progressive decline in memory and cognitive functions including judgment, decisionmaking, orientation to physical surroundings, and language. Many diseases are able to cause a

Holger Stark, Johann Wolfgang GoetheUniversität, Institut für Pharmazeutische Chemie, ZAFES/CMP, Max-von-LaueStr. 9, 60438 Frankfurt/Main, Germany

@ h.stark@pharmchem.uni-frankfurt.de

些 +49-69 - 79829302

且 $\quad+49-69-79829258$ dementia syndrome, but Alzheimer's disease (AD) and cerebrovascular ischemia (vascular dementia) are the two most common. Some cases of dementia involve both of these disorders. The prevalence of dementia is rapidly rising as the percentage of older people in the population increases. It has been estimated that about $5 \%$ of adults over 65 years are affected by AD (Bullock 2004). Roughly speaking, age constitutes the main risk factor for dementia. In view of our ageing society, both the number of dementia patients and the economic and social impacts of dementia are expected to grow dramatically. It is forecast that the worldwide number of elderly people suffering from dementia will rise to 63 million in 2030 (65\% of those in less-developed regions), and to 114 million in 2050 (74\% of those in less-developed regions) (Wimo et 
al. 2003). There is an enormous need to develop both means of earlier clinical diagnosis and novel therapeutic strategies.

Alzheimer's disease is characterized by extracellular neuronal plaques that contain the $\beta$ amyloid peptide and intracellular neurofibrillary tangles (NFT), which are composed of hyperphosphorylated forms of the $\tau$ (tau)-protein. The condition is accompanied by decreased synaptic density, which may lead to widespread neurodegeneration, loss of synapses, and failure of neurotransmitter pathways. The cognitive deterioration associated with vascular dementia is caused by occlusion of cerebral arteries and loss of cerebral tissue as a consequence of hypertension, diabetes, heart disease, or stroke.

Cholinergic deficits in the brain are invariably found in models of animal cognitive impairment, ageing humans and those with neurodegenerative diseases (Passani and Blandina 2004). Basic and clinical studies have shown that the degeneration of cholinergic basal forebrain neurons innervating the cortex is linked to cognitive decline (Everitt and Robbins 1997, Passani and Blandina 2004). The central function of acetylcholine (ACh) in cognitive processes is generally accepted, though its precise roles remain to be defined. Patients with dementias of various aetiologies have similar decreases in ACh concentration, which implies a similar pathogenesis in the process of cognitive impairment involved in the various disorders (Jia et al. 2004). The central role of this neurotransmitter in cognitive processes does not imply exclusivity, however: a Medline search with the keywords "memory" and various "neurotransmitters" and the limitation for "title words" revealed that essentially all major neurotransmitters have been associated with roles in cognition. An informal (and of course non-representative) "top 10" enumerational list has NMDA in the top spot, followed by dopamine, ACh ( $3^{\text {rd }}$ rank!), insulin, serotonin, and histamine (special emphasis will be placed on histaminergic neurotransmission later in this paper). According to the same survey, the other catecholamines (epinephrine and norepinephrine) and GABA are in the minor leagues of cognition-supporting endogenous substances. At the end of the list are substance $\mathrm{P}$ and the vasoactive intestinal peptide (VIP), with one order of magnitude fewer papers referring to them than the top players.

Malfunction of these neurotransmitter systems may elicit additive or even synergistic effects in conjunction with the cholinergic dysfunction. They are representative of the complex regulation of brain systems affecting cognitive processes (Decker and McGaugh 1991, Givens and Sarter 1997).

\section{The Past}

Why does ACh hold a preferential position in our perception? That might have more to do with opportunity than with true desire: inhibitors of various ACh receptors abound in nature, and plants containing them may derive an evolutionary advantage from their ill effects on the mammals that ingest them. The same either does not apply to other neurotransmitter systems, or if it does, then only to a lesser extent. There is a long history of the love-hate relationships between men (and of course women) and drugs and more generally manipulations of the cholinergic system; essentially every mythology (e.g., Greek, Roman, and Indian) contains similar allusions to magic brews that alter the mind of the recipient.

From a pharmacological perspective, the pinnacle is in the Odyssey, the Homeric description of the encounter of Odysseus (King of Ithaca) with the beautiful sorceress Circe on the island of Aeaea. From a Eurocentric perspective, this story reflects perhaps the best known and the earliest (about 3000 years ago) empirical knowledge of the clinical effects of an anticholinergic substance and the therapeutic efficacy of a cholinesterase-inhibitor antidote (Block 2007).

In brief, when Odysseus and his comrades-inarms arrived on Aeaea, parts of the crew took a land trip and enjoyed a party given by Circe. At the banquet, they were poisoned with drugs which made them "forget their fatherland and their desire to return to it," and probably also many other things (memory impairment). The sailors also believed they were transformed into animals (delusionalhallucinatory state).

The signs and symptoms described are in line with those induced by the antimuscarinic agents contained in numerous plants: the toxidrome commonly referred to as Central Anticholinergic Syndrome (CAS) (according to Plaitakis and Duvoisin), the drug given to the crew was in all likelihood an atropine-containing extract from Datura stramonium (thorn apple, or jimsonweed) (Plaitakis and Duovisin 1983). Odysseus (with some divine help) set out to save his men. Hermes (at the time in charge of free trade) showed Odysseus the plant containing the needed antidote, which the gods called moly.

The description of the antidote, and the immunity it gave Odysseus, which allowed him to rescue his crew from Circe and to recover their memories, suggest that moly is the acetylcholinesterase inhibitor galantamine, derived from the snowdrop (Galanthus nivalis or Galanthus woronowii) (Plaitakis and Duovisin 1983).

As recently as the mid nineteenth century, acetylcholinesterase inhibitors were used on their own to induce mind alterations. Lacking a better judicial system, the natives of Old Calabar, an eastern province of Nigeria, believed in the power of the seeds of a local plant called "chop nut" to determine whether individuals were innocent or guilty. The story of "chop nut" (Physostigma 
venenosum) and the fundamental Scottish contribution to physostigmine toxicology was recently excellently told by Proudfoot (2006).

Nineteenth-century ophthalmologists were already familiar with the different effects of atropine (mydriasis) and physostigmine (miosis) on the pupil. The knowledge of the mydriatic actions of antimuscarinics is in fact millennia old. Atropine extracts were used by Cleopatra in the last century B.C. to dilate her pupils, in the hope that she would appear more alluring. In the Renaissance, women used the juice of the berries of Atropa belladonna (Deadly Nightshade) to enlarge their pupils for the same reason; bella donna is Italian for 'beautiful woman'.

The miotic effect of "chop nut" was recognized as soon as sufficient quantities of the plant became available to experiment-friendly European physicians. One of the first to report on physostigmine-induced miosis was Argyll Robertson in 1863 (Proudfoot 2006). With the synthesis of physostigmine (eserine) by P.L. Julian and J. Pikl in 1935, this carbamate derivative, a reversible inhibitor of cholinesterase, became widely available (Julian and Pikl 1935).

At about the same time began the era of irreversible inhibitors of cholinesterase: the organophosphates and organophosphonates. The names associated with the development of these compounds are Willy Lange and his student Gerda von Krueger and Gerhard Schrader in Germany and Bernard C. Saunders in the UK. While these names are known to everyone interested in cholinergic pharmacology, those associated with the first synthesis of an organophosphate cholinesterase inhibitor are little known: De Clermont and Moschnin, two French scientists, synthesized tetraethyl pyrophosphate (TEPP) in 1854, while working in the laboratory of Wuertz (Holmstedt 1963).

It was assumed for a long time that carbamate cholinesterase inhibitors are "natural products" as opposed to organophosphates and organophosphonates, which were considered synthetic or man-made. Recently, however, natural organophosphate cholinesterase inhibitors produced by Streptomyces antibioticus have been described (Neumann and Peter 1987).

\section{The Present}

The group of clinically available drugs for dementia is rather small: Four cholinesterase inhibitors and a NMDA-receptor antagonist.

\section{Plugging the sink: cholinesterase inhibitors}

Tacrine (Cognex ${ }^{\circledR}$, Figure 1, (2)): Tacrine is structurally an 1,2,3,4-tetrahydroacridine-10-amine and acts as a reversible inhibitor of both plasma esterase and acetylcholinesterase. It was the first centrally acting cholinesterase inhibitor approved for the treatment of $\mathrm{AD}$ and was marketed under the trade name Cognex. The story of the development of tacrine began in 1940, with its synthesis as an intravenous antiseptic by Adrian Albert at the University of Sydney, Australia. In the 1970s, William Summers began using tacrine in treating drug overdose coma and delirium. He felt it might have application in Alzheimer's treatment based on work done in England by Peter Davies. In 1981, Summers et al. gave intravenous tacrine to Alzheimer's patients, who improved measurably (Summers 2006). Tacrine showed poor bioavailability and a short half-life requiring qid administration. Because of a high incidence of increases in liver transaminases under tacrine therapy (tacrine transaminitis), the substance is de facto not used anymore (Green et al. 1995).

Donepezil $\quad$ (Aricept ${ }^{\circledR}, \quad 2-[(1-$ benzyl-4piperidyl)methyl]-5,6-dimethoxy-2,3-dihydroinden1-one) (Figure 2, (2)): Donepezil, a piperidine derivative, is also a reversible inhibitor of acetylcholinesterase, but with a fast onset. It has excellent oral bioavailability and easily crosses the blood-brain barrier. Because of its long half-life, it need only be taken once a day. Donepezil was developed by Sugimoto et al. at the Tsukuba Research Laboratories for Drug Discovery, Eisai Company, Japan (Sugimoto et al. 2002).

Rivastigmine (Exelon ${ }^{\circledR}$, (S)- $N$-ethyl- $N$-methyl3-[1-(dimethylamino)ethyl]phenyl carbamate) (Figure 2, (3)): This substance, synthesized by Weinstock et al. at the Hebrew University of Jerusalem, Israel, and developed to market by Novartis, was approved by the FDA for treatment of $\mathrm{AD}$ in 2000. While tacrine and donepezil are classified as short-acting or reversible agents, since binding to acetylcholinesterase enzyme (AChE) is hydrolyzed within minutes, rivastigmine is classified as an intermediate-acting or pseudoirreversible agent because it inhibits AChE for up to several hours. Preclinical biochemical studies indicated that rivastigmine might have some central nervous system selectivity over peripheral inhibition. Further advantages of this carbamate are a metabolism independent of hepatic cytochrome P450 enzymes (pK properties remain essentially unaltered in patients with renal or hepatic impairment) and its availability as a transdermal patch formulation (Jann 2000). In 2006, it became the first product approved globally for the treatment of the dementia associated with Parkinson's disease.

Galantamine (Razadyne ${ }^{\circledR}, \quad(4 \mathrm{a} S, 6 R, 8 \mathrm{a} S)-$ 4a,5,9,10,11,12-hexahydro-3-methoxy-11-methyl6H-benzofuro[3a,3,2-ef][2]benzazepin-6-ol)

(Figure 2, (4)): An alkaloid of plant origin, galantamine is a competitive, fast-onset reversible inhibitor of esterases (Lane et al. 2006). It shows a 50-fold selectivity for acetylcholinesterase over plasma cholinesterase (BChE) (Krall et al. 1999). 
The compound was FDA-approved for treatment of A) in 2001. Following the deaths of two patients after they were mistakenly given a diabetes medication glimepiride (Amaryl) instead of the Alzheimer's medication galantamine (Reminyl), the manufacturer Ortho-McNeil Neurologics decided to change the latter's name. Effective from July 2005, the Alzheimer's medication changed its name from Reminyl to Razadyne. There have since been reports of another name confusion, between
Razadyne and Rozerem (the trade name for Ramelteon, a medication for the treatment of insomnia, marketed by Takeda) (http://www.rxforsafety.com/news/index.htm accessed on April 19, 2007). Ramelteon is the first in a new class of sleep agents that selectively bind to the melatonin receptors $\left(\mathrm{MT}_{1}\right.$ and $\left.\mathrm{MT}_{2}\right)$ in the suprachiasmatic nucleus (SCN).

TACRINE

5 humans $\mathrm{IC}_{50}=202 \pm 5 \mathrm{nM}(\mathrm{Cl} 95 \%$ 190-214)

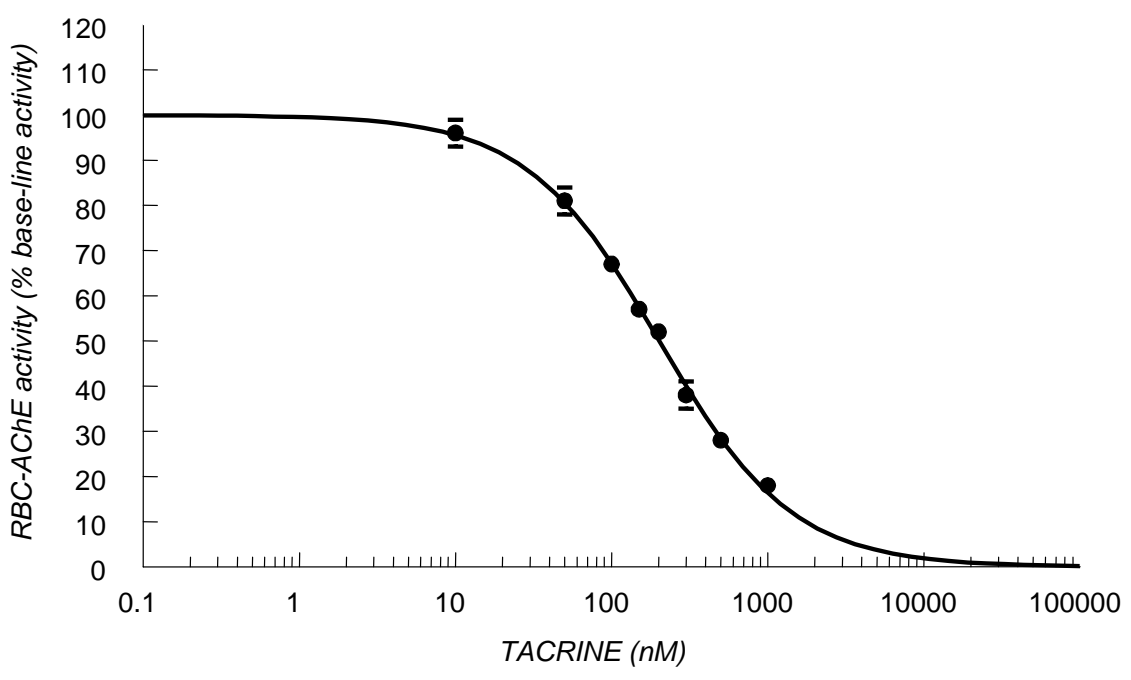<smiles>Nc1c2c(nc3ccccc13)CCCC2</smiles>

(1)

Tacrine

Fig. 1. Tacrine is a potent inhibitor of red blood cell - AChE, with an $\mathrm{IC}_{50}$ of about $200 \mathrm{nM}$.

The "better magnesium"

Memantine $\quad\left(\right.$ Namenda ${ }^{\circledR}$; $\quad$ Axura $^{\circledR}$, 3,5dimethyladamantane-1-amine) (Figure 2, (5)): Glutamate as an agonist at ionotropic excitatory receptors (NMDA) plays an important role in memory function and information processing. It appears that $\beta$-amyloid (available in excess as in Alzheimer's disease) inhibits glutamate recycling and leads to glutamate accumulation and therefore over-excitation and masking of signal transmission (unfavorable noise-to-signal ratio). Memantine restores physiological transmission by blocking NMDA receptors.

As a result of its less pronounced voltage dependency, memantine is more effective than $\mathrm{Mg}^{2+}$ in blocking pathological activation of NMDA receptors. However, following strong synaptic activation, memantine, like $\mathrm{Mg}^{2+}$, can also leave the 
NMDA receptor channel. Compared to the body's own NMDA antagonist magnesium, memantine is described as a "better magnesium" (Rogawski and Wenk 2003, Lipton 2004). In addition to having NMDA effects, memantine is also a potent antagonist at serotonin $5-\mathrm{HT}_{3}$ receptors and a weak antagonist at neuronal nicotinic receptors. Memantine has an excellent bioavailability of close to $100 \%$ and a long half-life similar to that of donepezil (60-90 hours). Hepatic CYP metabolism is minimal; most of the drug is excreted renally, either unchanged or conjugated. Memantine is generally co-administered with a cholinesterase inhibitor, the pairing with donezepil being advantageous because of its comparable half-life.

\section{The future: nitromemantines}

The role of nitrosylation in control of NMDAreceptor functioning is superbly explained by Stuart Lipton, who is the father of the "nitromemantines" (Lipton 2004). In brief, while several cysteine residues on the NMDA receptor can be nitrosylated, cysteine 399 seems to mediate over $90 \%$ of the NO effect on the NMDA receptor. Nitrosylation at this site modulates NMDA-receptor functioning, reducing $\mathrm{Ca}^{2+}$ influx into the cell and thus reducing excitotoxicity. Nitromemantines are perceived to have great potential as NMDA modulators.
Turning on the ACh tap:stimulation of $5-\mathrm{HT}_{4}$ receptors

5- $\mathrm{HT}_{4}$ receptor agonists have been around for some time and have been employed, with mixed results, in the treatment of gastrointestinal disease. Some of the best-known examples are cisapride (Propulsid ${ }^{\circledR}$ ), a gastrokinetic drug, and tegaserod (Zelnorm $^{\circledR}$ ), used for the management of irritable bowel syndrome with constipation. More recently, mosapride (Gasmotin ${ }^{\circledR}$ ) has been marketed by Dainippon Sumitomo Pharma as a gastrokinetic drug. Marketing of both cisapride and tegaserod has been restricted in the United States because of their torsadogenic potential (potassium channel blockade); however, their main mode of therapeutic action was the release of acetylcholine via activation of the serotonin $5-\mathrm{HT}_{4}$ receptor. In addition, $5-\mathrm{HT}_{4}$ activity is associated with an increased excretion of a soluble form of the amyloid precursor protein sAPP $\alpha$ (the "good" APP). The insoluble form of this protein (the "bad" APP) deposits in plaques in the brains of Alzheimer's patients. Thus, increasing the good APP is believed to be advantageous. Centrally acting $5-\mathrm{HT}_{4}$ receptor agonists are a promising new avenue in Alzheimer's research being pursued by some of the major drug companies.<smiles>COc1cc2c(cc1OC)C(=O)C(CC1CCN(Cc3ccccc3)CC1)C2</smiles>

(2)

Donepezil<smiles>COc1ccc2c3c1O[C@H]1CC(O)C=C[C@]34CCN(C)CC[C@@]24C1</smiles>

(4)

Galantamine<smiles>CCN(C)C(=O)Oc1cccc(C(C)N(C)C)c1</smiles>

(3)

\section{Rivastigmine}<smiles>C[C@@]12CC3CC(N)(C1)C[C@@](C)(C3)C2</smiles>

(5)

Memantine

Fig. 2. Group of clinically available drugs used primarily for treatment of dementia. 


\section{Histaminergic neurotransmission}

The histaminergic system is strongly associated with numerous activities of arousal, learning and memory, neuroendocrine regulation, vascular function, and processes in the central nervous system (Panula et al. 1997). Since systemically applied histamine does not cross the blood-brain barrier, the central nervous system (CNS) depends upon local neuronal biosynthesis. Morphological features such as compact and widespread distribution of the varicose fibers suggest that the central histaminergic system may act as a main regulatory centre for whole-brain activity and interact with numerous other neurotransmitters (Brown et al. 2001, Wada et al. 1991).

Histamine has been called a "waking amine," because it has been shown that histaminergic activity increases significantly during awake periods (Monti 1993). The diurnal changes in brain histamine levels indicate a twenty-four hour rhythm (Orr and Quay 1984); for example, the catabolic activity of histamine $N^{\tau}$-methyltransferase (HMT) is higher during darkness (Tuomisto and Tuomisto 1982).

Four distinct histamine receptor subtypes $\left(\mathrm{H}_{1}-\right.$ $\mathrm{H}_{4}$ ) have been identified, and all are $\mathrm{G}$ proteincoupled receptors. They are all found in different<smiles>S=C(NC1CCCCC1)N1CCC(c2c[nH]cn2)CC1</smiles>

Thioperamide<smiles>CNC(=O)c1ccc(Oc2ccc3c(c2)CCN(C2CCC2)CC3)nc1</smiles>

(8)

GSK189254

Fig. 3. Structures of potent $\mathbf{H}_{3}$ receptor antagonists.

Inhibition of cortical acetylcholine release by $\mathrm{H}_{3}$ receptor activation is indirect and appears to be mediated by GABAergic interneurons in the cortex (Giorgetti et al. 1997, 2000). Endogenous histamine exerts a tonic influence on cholinergic neurotransmission, enhancing cholinergic activity at the level of cholinergic cell bodies in the basal forebrain (Mochizuki et al. 1994, Cecchi et al. concentrations in the CNS (Ligneau et al. 2000, Cogé et al. 2001). $\mathrm{H}_{3}$ receptors occur both as autoreceptors on histaminergic nerve endings, controlling synthesis as well as release of histamine by a negative feedback mechanism (Arrang et al. 1987, Prast et al. 1994), and as heteroreceptors, modulating the release of numerous other neurotransmitters (e.g., glutamate, dopamine, ACh, noradrenaline, serotonin, GABA, some peptides and co-transmitters) (Schlicker et al. 1988, 1989, 1993, 1999, Chotard et al. 2002).

In addition to having profound effects on arousal, $\mathrm{H}_{3}$ receptors have been reported to play a strong role in cognition (Wada et al. 1991, Passani and Blandina 1998). The histaminergic system has a neuromodulatory effect on cholinergic transmission via $\mathrm{H}_{3}$ receptor-mediated inhibition in different brain areas, rat hippocampus (Bacciottini et al. 2002), cortex (Blandina et al. 1996), ventral striatum (Prast et al. 1997), and basolateral amygdale (Passani et al. 2001). $\mathrm{H}_{3}$ receptors modulate acetylcholine release differently, depending on the brain region and the neurological status (Passani et al. 2004).<smiles>Clc1ccc(CCCOCCCN2CCCCC2)cc1</smiles>

(7)

BF2.649<smiles>c1ccc2c(NCCc3ccc(OCCCN4CCCCC4)cc3)c3c(nc2c1)CCCC3</smiles>

(9)

FUB 833
1998, Bacciottini et al. 1999). Selective antagonists and inverse agonists block $\mathrm{H}_{3}$ autoreceptors and stimulate ACh release.

Along with ACh interactions of $\mathrm{H}_{3}$ receptors, histamine modulates NMDA receptors (Bekkers 1993). Although this effect is not mediated via histamine receptors, the histamine liberated by $\mathrm{H}_{3}$ blockade may facilitate long-term potentiation 
(Selbach et al. 1997), providing additional support for a central role of histamine in cognition.

\section{$\mathrm{H}_{3}$ Receptor antagonists in cognition models}

Numerous histamine $\mathrm{H}_{3}$ receptor antagonists have demonstrated procognitive effects in memory consolidation models. In step-through passive avoidance responding, a model relevant to memory consolidation, thioperamide as a classical reference antagonist reversed impairment in memory and learning in a mouse strain with premature senescence (Meguro et al. 1995).

The utility of $\mathrm{H}_{3}$ receptor antagonists in neurodegenerative disorders is shown in passive avoidance and novel object recognition tests (Giovannini et al. 1999), the Morris water maze, Barnes maze and elevated plus maze models (Hancock and Fox 2004), and models of attention and impulsivity, as well as multiple-choice serial reaction time tasks (Muir et al. 1994, Everitt et al. 1995); $\mathrm{H}_{3}$ receptor antagonists also attenuate slowwave electroencephalograph activity. These effects are consistent with increased alertness, vigilance, and attention (Table 2) (Ligneau et al. 1998).

As many early potent histamine $\mathrm{H}_{3}$ receptor antagonists containing an imidazole moiety showed potential limitations concerning selectivity and especially pharmacokinetic properties (CYP interaction), the development shifted to so-called non-imidazole derivatives, which are currently in various clinical phases (LaBella et al. 1992, Ganellin et al. 1998, Ligneau 2000, Lovenberg et al. 2000, Hough 2001, Ireland-Denny et al. 2001, Liu et al. 2001, Hahn et al. 2002, Yang et al. 2002, Yao et al. 2003, Esbenshade et al. 2003).

Different interesting compounds are shown in Figure 3. The outcome of $\mathrm{H}_{3}$ receptor antagonist testing in different models of memory, cognition, and related topics has been proved many times (Table 2). The cognitive performance of rat pups was improved in a five-trial avoidance test (attention test) (Esbenshade et al. 2003, Esbenshade et al. 2004, Fox et al. 2005). The social memory effect was also significantly enhanced in the adult rat (Esbenshade et al. 2003, Esbenshade et al. 2004) The social memory test relies on the retention in the memory of olfactory cues, which allow an adult rat to recall a social interaction with a novel juvenile rat for a period of time.

Several potent $\mathrm{H}_{3}$ antagonists applied orally provided an increase in wakefulness without influencing the locomotor effect. These antagonists have not produced any alteration of the EEG power spectral activity in contrast to amphetamine and therefore preserve the qualitative aspect of vigilance (Leurs et al. 2005, Ligneau et al. 2007). Beside the wakefulness promoting effect both compounds demonstrated in mice or rats, they also showed an anticataplectic effect in dogs, which was comparable to that of desipramine (a tricyclic antidepressent used to treat human cataplexy) (Bonaventure et al. 2007).

Pharmacological evaluation of different $\mathrm{H}_{3}$ receptor antagonists proved this class of drugs to be a promising candidate to be developed for the treatment of memory deficits and other cognitive disorders. The compounds increased dopamine and acetylcholine levels in microdialysates of the prefrontal cortex; enhanced fast cortical electroencephalograph rhythms, known to be associated with improved vigilance; and had a marked waking effect. These results, as well as the effect on the two-trial object recognition test in mice (with either scopolamine-induced or natural forgetfulness), underlined the therapeutic potential of these drugs for treating cognitive deficits in $\mathrm{AD}$, other dementias, or attention deficit-hyperactivity disorders (ADHD) (Giovannini et al. 1999, Stark 2004a, Leurs et al. 2005, Bonaventura et al. 2007, Ligneau et al. 2007).

\section{Hybrid compounds - multiple targeting}

Combinations of different pharmacological properties in one molecule may produce synergistic effects, i.e., the whole becomes more than the sum of its parts. Dual $\mathrm{H}_{3}$ receptor and $\mathrm{M}_{2}$ receptor antagonists have been patented for potential use in AD (Ting et al. 2003). Tacrine has been another chemical starting point of numerous hybrid compounds with dual targeting (Munoz-Torrero and Camps 2006). Here it is of special interest that tacrine is also a potent inhibitor of histamine $N^{\tau}$ methyltransferase (HMT) (Cumming and Vincent 1992, Morisset et al. 1996, Grassmann et al. 2003, Apelt et al. 2005). Inhibition of $\mathrm{H}_{3}$ autoreceptors would lead to an increased release of histamine due to the inhibition of the negative feedback mechanism. At the same time, competitive inhibition of the catabolic HMT would prevent metabolism of the histamine released. This dual action should lead to a massive and sustained release of histamine within the brain. By combination of antagonist $\mathrm{H}_{3}$ receptor and inhibitory HMT pharmacophores a new hybrid approach has been realized (Meier et al. 2001) (Figure 3, (9)). For certain compounds (Stark 2004b, Apelt et al. 2005), additional inhibitory activities on AChE and butyrylcholinesterase (BChE) were demonstrated, leading to a quadruple activity profile (Petroianu et al. 2005).

\section{Conclusion}

Cognitive impairment is a dramatically increasing problem affecting many individuals as well as the health system. As we have no causal treatment for the loss of memory, symptomatic treatment is needed. Influencing the ACh system is a generally accepted approach, although other therapeutic treatments are in various stages of development (Burns and O’Brien, 2006, Melnikova 2007). 
Table 1: Overview of the clinically available cholinesterase inhibitors (Krall et al. 1999, Cummings 2000, Delagarza 2003, Lipton 2004, Lane et al. 2006, Lleo et al. 2006).

\begin{tabular}{|c|c|c|c|c|c|c|c|}
\hline Substance & Trade name & Chemical structure & Inhibits & $\mathrm{t} 1 / 2$ (min) & $\begin{array}{c}\text { Protein } \\
\text { binding \% }\end{array}$ & Metabolism & $\mathrm{ADR}$ \\
\hline Tacrine & $\begin{array}{c}\text { Cognex } \\
1993\end{array}$ & Acridine & $\begin{array}{c}\text { reversible; non- } \\
\text { competitive } \\
\text { BChE>AChE }\end{array}$ & $\begin{array}{l}\text { 90-120 min } \\
\text { qid }\end{array}$ & 75 & $\begin{array}{c}\text { Hepatic } \\
\text { CYP } \\
\text { 1A2 \& 2D6 }\end{array}$ & $\mathrm{LFT} \uparrow$ \\
\hline Donepezil & $\begin{array}{c}\text { Aricept } \\
1996\end{array}$ & Piperidine & $\begin{array}{c}\text { reversible; mixed } \\
\text { AChE }>>> \\
\text { BChE }\end{array}$ & $\begin{array}{l}70 \text { hours } \\
\text { qid }\end{array}$ & $>90$ & $\begin{array}{c}\text { Hepatic } \\
\text { CYP } \\
\text { 3A4 \& 2D6 }\end{array}$ & $\begin{array}{c}\text { nausea } \\
\text { vomiting }\end{array}$ \\
\hline Rivastigmine & $\begin{array}{c}\text { Exelon } \\
2000\end{array}$ & Carbamate & $\begin{array}{l}\text { pseudo-irreversible; } \\
\text { non-competitive } \\
\text { AChE > BChE }\end{array}$ & $\begin{array}{l}10 \text { hours } \\
\text { bid }\end{array}$ & 40 & $\begin{array}{c}\text { Non-hepatic; } \\
\text { Esterases }\end{array}$ & $\begin{array}{c}\text { nausea } \\
\text { vomiting }\end{array}$ \\
\hline Galantamine & $\begin{array}{l}\text { Reminyl } \\
\text { Razadyne } \\
2001\end{array}$ & Alkaloid & $\begin{array}{c}\text { reversible; } \\
\text { competitive } \\
\text { AChE>BChE }\end{array}$ & $\begin{array}{l}\text { 5-9 hours } \\
\text { bid }\end{array}$ & $10-20$ & $\begin{array}{c}\text { Hepatic } \\
\text { CYP } \\
\text { 3A4 \& 2D6 }\end{array}$ & $\begin{array}{c}\text { nausea } \\
\text { vomiting }\end{array}$ \\
\hline
\end{tabular}


Table 2: Testing of $\mathbf{H}_{3}$ receptor antagonists on preclinical animal models of cognition disorders and related topics.

\begin{tabular}{|c|c|c|c|c|c|c|c|c|c|}
\hline \multirow[b]{2}{*}{ Test model } & \multirow{2}{*}{$\begin{array}{c}\text { Relevant } \\
\text { Human } \\
\text { Disease }\end{array}$} & \multicolumn{8}{|c|}{ Histamine $\mathrm{H}_{3}$ receptor antagonists } \\
\hline & & $\begin{array}{c}\text { Thioperamide } \\
\mathbf{( 6 )}^{1,2}\end{array}$ & Ciproxifan $^{3,4,5}$ & GT-2331 2,6 & A-304121 2,5 & ABT-239 $2,7,8$ & JNJ-5207852 & BF2.649 $(7)^{12}$ & $\begin{array}{c}\text { GSK189254 } \\
(\mathbf{8})^{10,11} \\
\end{array}$ \\
\hline Memory Consolidation & $\mathrm{AD}$ & + & & & & & & & + \\
\hline Spatial Orientation & $\mathrm{AD}$ & + & + & + & & + & + & & + \\
\hline Working Memory & $\mathrm{AD}$ & + & & & & & & & \\
\hline $\begin{array}{l}\text { Social Memory } \\
\text { (Short-term Memory) }\end{array}$ & $\begin{array}{l}\mathrm{AD} \\
\mathrm{ADHD}\end{array}$ & + & + & + & + & + & & + & \\
\hline $\begin{array}{l}\text { Attention/Impulsivity } \\
\text { Acquisition test in SH rat } \\
\text { 5-trail version }\end{array}$ & $\begin{array}{l}\mathrm{AD} \\
\mathrm{ADHD}\end{array}$ & + & + & + & + & + & + & + & + \\
\hline Locomotor activity & ADHD & no change & no change & no change & no change & no change & no change & no change & \\
\hline $\begin{array}{l}\text { Sensory Gating and Pre- } \\
\text { attention in mice }\end{array}$ & $\begin{array}{c}\text { ADHD } \\
\text { Schizo- } \\
\text { phrenia } \\
\text { AD }\end{array}$ & + & + & + & & + & + & & \\
\hline $\begin{array}{l}\text { Free moving EGG } \\
\text { Wakefulness state }\end{array}$ & $\begin{array}{l}\text { ADHD } \\
\text { Schizo- } \\
\text { phrenia }\end{array}$ & + & + & + & no change & + & + & + & \\
\hline
\end{tabular}

$+\quad$ Indicates efficacy in the test model for the specific compound

AD Alzheimer's disease, ADHD Attention-deficit hyperactivity disorder

${ }^{1}$ Meguro et al. 1995

${ }^{2}$ Hancock 2006

${ }^{3}$ Ligneau et al. 1998

${ }^{4}$ Fox et al.2002

${ }^{5}$ Fox et al. 2003

${ }^{6}$ Tedford et al. 1998

${ }^{7}$ Cowart et al. 2004a

${ }^{8}$ Cowart et al. 2004b

${ }^{9}$ Barbier et al. 2004

${ }^{10}$ Bamford et al. 2004

${ }^{11}$ Medhurst et al. 2007

${ }^{12}$ Ligneau et al. 2007 
The multiple target drug approach using hybrid compounds may be another optimized move forward for the treatment of cognitive disorders (Morphy et al. 2004, Roth et al. 2004, Stark 2004a). Since the complex neuronal regulation is slowly being decoded, there is hope that ways will be found to stop neuronal loss and to generate new synapses. This brief overview should be ended with a perspective citation from Corrie ten Boom: "Memories are the key not to the past, but to the future."

\section{REFERENCES}

Apelt J, Grassmann S, Ligneau X, Pertz HH, Ganellin CR, Arrang JM, Schwartz JC, Schunack W, Stark H: Search for histamine $\mathrm{H}_{3}$ receptor antagonists with combined inhibitory potency at $N$-methyltransferase: Ether derivatives. Pharmazie 60:79-106, 2005.

Arrang J, Garbarg M, Lancelot J, Lecomte JM, Pollard H, Robba M, Schunack W, Schwartz JC: Highly potent and selective ligands for histamine $\mathrm{H}_{3}$-receptors. Nature 327:117-123, 1987.

Bacciottini L, Mannaioni PF, Chiappetta M, Giovannini MG, Blandina P: Acetylcholine release from hippocampus of freely moving rats is modulated by thioperamide and cimetidine. Inflamm. Res. 48:63-64, 1999.

Bacciottini L, Giovannelli L, Passani MB, Schunack W, Mannaioni PF, Blandina P: Endogenous histamine in the medial septumdiagonal band complex increases the release of acetylcholine from the hippocampus: A dualprobe microdialysis study in the freely moving rat. Eur. J. Neurosci. 15:1669-1680, 2002.

Bamford MJ, Dean DK, Sehmi SS, Wilson DM, Witherington J: Benzodiazepine derivatives for the treatment of neurological disorders. WO 2004/056369, 2004.

Barbier AJ, Berridge C, Dugovic C, Laposky AD, Wilson SJ, Boggs J, Aluisio L, Lord B, Mazur C, Pudiak CM, Langlois X, Xiao W: Acute wake-promoting actions of JNJ-5207852, a novel, diamine-based $\mathrm{H}_{3}$ antagonist. $\mathrm{Br}$. J. Pharmacol. 143:649-661, 2004.

Bekkers JM: Enhancement by histamine of NMDAmediated synaptic transmission in the hippocampus. Science 261:104-106, 1993.

Blandina P, Giorgetti M, Bartolini L, Cecchi M, Timmerman H, Leurs R, Pepeu G, Giovannini MG: Inhibition of cortical acetylcholine release and cognitive performance by histamine $\mathrm{H}_{3}$ receptor activation in rats. Br. J. Pharmacol. 119:1656-1564, 1996.

Block W: Galantamine: Revives memory and helps fight

Alzheimer's. www.galantamine.cc/articles/galantaminearticles-5.htm (accessed on April 19, 2007).

Bonaventure P, Letavic M, Dugovic C, Wilson S, Aluisio L, Pudiak C, Lord B, Mazur C, Kamme F, Nishino S, Carruthers N, Lovenberg T: Histamine $\mathrm{H}_{3}$ receptor antagonists: From target indentification to drug leads. Biochem. Pharmacol. 73:1084-1096, 2007.

Brown RE, Stevens DR, Haas HL: The physiology of brain histamine. Prog. Neurobiol. 63:637672, 2001.

Bullock R: Future directions in the treatment of Alzheimer's disease. Expert Opin. Investig. Drugs 13:303-314, 2004.

Burns A, O’Brien J: Clinical practice with antidementia drugs: a consensus statement from British Association for Psychopharmacology. J. Psychopharmacol. 20:732-755, 2006.

Cecchi M, Giorgetti M, Bacciottini L, Giovannini MG, Blandina P: Increase of acetylcholine release from cortex of freely moving rats by administration of histamine into the nucleus basalis magnocellularis. Inflamm. Res. 47:3233, 1998.

Chotard C, Ouimet T, Morisset S, Sahm U, Schwartz JC, Trottier S: Effects of histamine $\mathrm{H}_{3}$ receptor agonist and antagonist on histamine co-transmitter expression in rat brain. J. Neural Transm. 109:293-306, 2002.

Cogé F, Guenin SP, Rique H, Boutin JA, Galizzi JP: Structure and expression of the human histamine $\mathrm{H}_{4}$ receptor gene. Biochem. Biophys. Res. Commun. 284: 301-309, 2001.

Cowart M, Faghih R, Gfesser G, Curtis M, Pratt JK, Bennani Y, Fox GB, Esbenshade TA, Hancock AA: The medicinal chemistry of novel $\mathrm{H}_{3}$ antagonists. Inflamm. Res. 53:69-70, 2004a.

Cowart M, Pratt JK, Stewart AO, Bennani YL, Esbenshade TA, Hancock AA: A new class of potent non-imidazole $\mathrm{H}_{3}$ antagonists: 2aminoethylbenzofurans. Bioorg. Med. Chem. Lett. 14:689-693, 2004b.

Cumming P, Vincent SR: Inhibition of histamine$\mathrm{N}$-methyltransferase (HNMT) by fragments of 9-amino-1,2,3,4-tetrahydroacridine (Tacrine) and by $\beta$-carbolines. Biochem. Pharmacol. 44: 989-992, 1992.

Cummings JL: Cholinesterase inhibitors; a new class of psychotropic compounds. Am. J. Psychiatry 157:4-15, 2000.

Decker JLM, McGaugh JL: The role of interactions between the cholinergic system and other neuromodulatory systems in learing and memory. Synapse 7:151-168, 1991.

Delagarza VW: Pharmacologic treatment of Alzheimer's disease: An update. Am. Fam. Physician 68:1365-1372, 2003.

Esbenshade TA, Krueger KM, Miller TR, Kang CH, Denny LI, Witte DG, Yao BB, Fox GB, Faghih R, Bennani YL, Williams M, Hancock 
AA: Two novel and selective nonimidazole histamine $\mathrm{H}_{3}$ receptor antagonists A-304121 and A-317920: I. In vitro pharmacological effects. J. Pharmacol. Exp. Ther. 305:887-896, 2003.

Esbenshade TA, Fox GB, Krueger KM, Baranowski JL, Miller TR, Kang CH, Denny LI, Witte DG, Yao BB, Pan JB, Faghih R, Bennani $\mathrm{Y}$ et al.: Pharmacological and behavioral properties of A-349821, a selective and potent human histamine $\mathrm{H}_{3}$ receptor antagonist. Biochem. Pharmacol. 68:933-945, 2004.

Everitt BJ, Robbins TW: Central cholinergic systems and cognition. Annu. Rev. Psychol. 48:649-684, 1997.

Everitt BJ, Robbins TW, Muir JL: Reversal of visual attentional dysfunction following lesions of the cholinergic basal forebrain by physostigmine and nicotine but not by the 5$\mathrm{HT}_{3}$ receptor antagonist, ondansetron. Psychopharmacology (Berl.) 118:82-92, 1995.

Fox GB, Pan JB, Esbenshade TA, Bennani YL, Black LA, Faghih R, Hancock AA, Decker MW: Effects of histamine $\mathrm{H}_{3}$ receptor ligands GT-2331 and ciproxifan in a repeated acquisition avoidance response in the spontaneously hypertensive rat pup. Behav. Brain Res. 131:151-161, 2002.

Fox GB, Pan JB, Radek RJ, Lewis AM, Bitner RS, Esbenshade TA, Faghih R, Bennani YL, Williams M, Yao BB, Decker MW, Hancock AA: Two novel and selective nonimidazole $\mathrm{H}_{3}$ receptor antagonists A-304121 and A-317920: II. In vivo behavioral and neurophysiological characterization. J. Pharmacol. Exp. Ther. 305:897-908, 2003.

Fox GB, Esbenshade TA, Pan JB, Radek RJ, Krueger KM, Yao BB, Browman KE, Buckley MJ, Ballard ME, Komater VA, Miner $\mathrm{H}$, Zhang M, Faghih $\mathrm{R}$ et al.: Pharmacological properties of ABT-239 [4-(2-\{2-[(2R)-2methylpyrrolidinyl]ethyl\}-benzofuran-5-

yl)benzonitrile]: II. Neurophysiological characterization and broad preclinical efficacy in cogntion and schizophrenia of a potent and selective histamine $\mathrm{H}_{3}$ receptor antagonist. J. Pharmacol. Exp. Ther. 313:176-190, 2005.

Ganellin CR, Leurquin F, Piripitsi A, Arrang JM, Garbarg M, Ligneau X, Schunack W, Schwartz JC: Synthesis of potent non-imidazole histamine $\mathrm{H}_{3}$-receptor antagonists. Arch. Pharm. 331:395-404: 1998.

Giorgetti M, Bacciottini L, Bianchi L, Giovannini MG, Cecchi M, Blandina P: GABAergic mechanism in histamine $\mathrm{H}_{3}$ receptor inhibition of $\mathrm{K}^{+}$-evoked release of acetylcholine from rat cortex in vivo. Inflamm. Res. 46:33-34, 1997.

Giorgetti M, Bacciottini L, Giovannini MG, Colivicchi MA, Goldfarb J, Blandina P.: Local
GABAergic modulation of acetylcholine release from the cortex of freely moving rats. Eur. J. Neurosci. 12:1941-1948; 2000.

Giovannini MG, Bartolini L, Bacciottini L, Greco L, Blandina P.: Effects of histamine $\mathrm{H}_{3}$ receptor agonists and antagonists on cognitive performance and scopolamine-induced amnesia. Behav. Brain Res. 104:147-155, 1999.

Givens B, Sarter M: Modulation of cognitive processes by transsynaptic activation of the basal forebrain. Behav. Brain Res. 84:1-22, 1997.

Graßmann S, Apelt J, Sippl W, Ligneau X, Pertz $\mathrm{HH}$, Zhao YH, Arrang JM, Ganellin CR, Schwartz JC, Schunack W, Stark H: Imidazole derivates as a novel class of hybrid compounds with inhibitory histamine $N$-methyltransferase potencies and histamine $\mathrm{hH}_{3}$ receptor affinities. Bioorg. Med. Chem. 11:2163-2174, 2003.

Green VJ, Pirmohamed M, Kitteringham NR, Knapp MJ, Park BK: Glutathione S-transferase mu genotype $\left(\mathrm{GSTM}{ }^{*} 0\right)$ in Alzheimer's patients with Tacrine transaminitis. Br. J. Clin. Pharmacol. 39:411-415, 1995.

Hahn B, Shoaib M, Stolerman IP: Nicotine-induced enhancement of attention in the five-choice serial reaction time task: The influence of task demands. Psychopharmacology (Berl.) 162:129-137, 2002.

Hancock AA, Fox GB: Perspectives on cognitive domains, $\mathrm{H}_{3}$ receptor ligands and neurological disease. Expert Opin. Investig. Drugs 13: 1237-1248, 2004.

Hancock AA: The challenge of drug discovery of a GPCR target: Analysis of preclinical pharmacology of histamine $\mathrm{H}_{3}$ antagonists/inverse agonists. Biochem. Pharmacol. 71:1103-1113, 2006.

Holmstedt B: Structure-activity relationship of the organophosphorus anticholinesterase agents. In Koelle GB (ed): Cholinesterases and Anticholinesterase Agents, Berlin, 1963, pp. 429-485.

Hough LB: Genomics meets histamine receptors: New subtypes, new receptors. Mol. Pharmacol. 59:415-419, 2001.

Ireland-Denny L, Parihar AS, Miller TR, Kang $\mathrm{CH}$, Krueger KM, Esbenshade TA, Hancock AA: Species-related pharmacological heterogeneity of histamine $\mathrm{H}_{3}$ receptors. Eur. J. Pharmacol. 433:141-150, 2001.

Jann MW: Rivastigmine, a new-generation cholinesterase inhibitor for the treatment of Alzheimer's disease. Pharmacotherapy 20:112, 2000.

Jia JP, Jia JM, Zhou WD, Xu M, Chu CB, Yan X, Sun YX: Differential acetylcholine and choline concentrations in the cerebrospinal fluid of 
patients with Alzheimer's disease and vascular dementia. Chin. Med. J. 117:1161-1164, 2004.

Julian PL, Pikl J: The complete synthesis of Physostigmine (Eserine). J. Am. Chem. Soc. 57:755-757, 1935.

Krall WJ, Sramek JJ, Cutler NR: Cholinesterase inhibitors: A therapeutic strategy for Alzheimer's disease. Ann. Pharmacother. 33: 441-450, 1999.

LaBella FS, Queen G, Glavin G, Durant G, Stein D, Brandes LJ: $\mathrm{H}_{3}$ receptor antagonist, thioperamide, inhibits adrenal steroidogenesis and histamine binding to adrenocortical microsomes and binds to cytochrome P450. Br. J. Pharmacol. 107:161-164, 1992.

Lane RM, Potkin SG, Enz A: Targeting acetylcholinesterase and butyrylcholinesterase in dementia. Int. J. Neuropsychopharmacol. 9: 101-124, 2006.

Leurs R, Bakker RA, Timmerman H, de Esch IJ: The histamine $\mathrm{H}_{3}$ receptor: From gene cloning to $\mathrm{H}_{3}$ receptor drugs. Nat. Rev. Drug Discov. 4: 107-120, 2005.

Ligneau X, Lin J, Vanni-Mercier G, Jouvet $M$, Muir JL, Ganellin CR, Stark H, Elz S, Schunack W, Schwartz J: Neurochemical and behavioral effects of Ciproxifan, a potent histamine $\mathrm{H}_{3}$-receptor antagonist. J. Pharmacol. Exp.Ther. 287:658-666: 1998.

Ligneau X, Morisset S, Tardivel-Lacombe J, Gbahou F, Ganellin CR, Stark H, Schunack W, Schwartz JC, Arrang JM: Distinct pharmacology of rat and human histamine $\mathrm{H}_{3}$ receptors: Role of two amino acids in the third transmembrane domain. Br. J. Pharmacol. 131:1247-1250, 2000.

Ligneau X, Perrin D, Landais L, Camelin JC, Calmels TP, Berrebi-Bertrand I, Lecomte JM, Parmentier R, Anaclet C, Lin JS, BertainaAnglade V, la Rochelle CD: BF2.649 [1-\{3-[3(4-Chlorophenyl)propoxy]propyl $\}$ piperidine, hydrochloride], a nonimidazole inverse agonist/antagonist at the human histamine $\mathrm{H}_{3}$ receptor: Preclinical pharmacology. J. Pharmacol. Exp. Ther. 320:365-375, 2007.

Lipton SA: Failures and successes of NMDA receptor antagonists: molecular basis for the use of open-channel blockers like memantine in the treatment of acute and chronic neurologic insults. NeuroRx 1:101-110, 2004.

Liu C, Ma X, Jiang X, Wilson SJ, Hofstra CL, Blevitt J, Pyati J, Li X, Chai W, Carruthers N, Lovenberg TW: Cloning and pharmacological characterization of a fourth histamine receptor $\left(\mathrm{H}_{4}\right)$ expressed in bone marrow. Mol. Pharmacol. 59:420-426, 2001.

Lleo A, Greenberg SM, Growdon JH: Current pharmacotherapy for Alzheimer disease. Annu. Rev. Med. 57:513-533, 2006.
Lovenberg TW, Pyati J, Chang H, Wilson SJ, Erlander MG.: Cloning of rat histamine $\mathrm{H}_{3}$ receptor reveals distinct species pharmacological profiles. J. Pharmacol. Exp. Ther. 293:771-778, 2000.

Medhurst AD, Atkins AR, Beresford IJ, Brackenborough K, Briggs MA, Calver AR, Cilia J, Cluderay JE, Crook B, Davis JB, Davis RK, Davis RP et al.: GSK189254 - a novel $\mathrm{H}_{3}$ receptor antagonist that binds to histamine $\mathrm{H}_{3}$ receptors in Alzheimer's Disease brain and improves cognitive performance in preclinical models. J. Pharmacol. Exp. Ther. 321:10321045, 2007.

Meguro KI, Yanai K, Sakai N, Sakurai E, Maeyama $\mathrm{K}$, Sasaki H, Watanabe $\mathrm{T}$ : Effects of thioperamide, a histamine $\mathrm{H}_{3}$ antagonist, on the step-through passive avoidance response and histidine decarboxylase activity in senescenceaccelerated mice. Pharmacol. Biochem. Behav. 50:321-325, 1995.

Meier G, Apelt J, Reichert U, Grassmann S, Ligneau X, Elz S, Leurquin F, Ganellin CR, Schwartz JC, Schunack W, Stark H: Influence of imidazole replacement in different structural classes of histamine $\mathrm{H}_{3}$-receptor antagonists. Eur. J. Pharm. Sci. 13: 249-259, 2001.

Melnikova I: Therapies for Alzheimer's disease. Nat. Rev. Drug Discov. 6:341-342, 2007.

Mochizuki T, Okakura-Mochizuki K, Horii A, Yamamoto Y, Yamatodani A: Histaminergic modulation of hippocampal acetylcholine release in vivo. J. Neurochem. 62:2275-2282, 1994.

Monti JM: Involvement of histamine in the control of the waking state. Life Sci. 53:1331-1338, 1993.

Morisset S, Traiffort E, Schwartz JC: Inhibition of histamine versus acetylcholine metabolism as a mechanism of Tacrine activity. Eur. J. Pharmacol. 315:R1-R2, 1996.

Morphy R, Kay C, Rankovic Z: From magic bullets to designed multiple ligands. Drug Discov. Today 9:641-651, 2004.

Muir JL, Everitt BJ, Robbins TW: AMPA-induced excitotoxic lesions of the basal forebrain: a significant role for the cortical cholinergic system in attentional function. J. Neurosci. 14: 2313-2326, 1994.

Munoz-Torrero D, Camps P: Dimeric and hybrid anti-Alzheimer drug candidates: Curr. Med. Chem. 13:399-422, 2006.

Neumann R, Peter HH: Insecticidal organophosphates: Nature made them first. Experientia 43: 1235-1237, 1987.

Orr EL, Quay WB: The effects of castration on histamine levels and 24-hour rhythm in the male rat hypothalamus. Endocrinology 96:941945, 1984. 
Ortho-Mcneil

neurologics: http://www.rxforsafety.com/news/index.htm (accessed on April 19, 2007).

Panula P, Rinne J, Kuokkanen K, Eriksson KS, Sallmen T, Kalimo H, Relja M: Neuronal histamine deficit in Alzheimer's disease. Neuroscience 82:993-997, 1997.

Passani MB, Blandina P: Cognitive implications for $\mathrm{H}_{3}$ and $5-\mathrm{HT}_{3}$ receptor modulation of cortical cholinergic function: A parallel story. Methods Find Exp. Clin. Pharmacol. 20: 725-733, 1998.

Passani MB, Blandina P: The neuronal histaminergic system in cognition. Curr. Med. Chem. CNS Agents. 4:17-26, 2004.

Passani MB, Cangioli I, Baldi , Bucherelli C, Mannaioni PF, Blandina P: Histamine $\mathrm{H}_{3}$ receptor-mediated impairment of contextual fear conditioning and in-vivo inhibition of cholinergic transmission in the rat basolateral amygdala. Eur. J. Neurosci. 14:1522-1532, 2001.

Passani MB, Lin JS, Hancock A, Crochet S, Blandina P: The histamine $\mathrm{H}_{3}$ receptor as a novel therapeutic target for cognitive and sleep disorders. Trends Pharmacol. Sci. 25:618-625, 2004.

Petroianu G, Arafat K, Sasse BC, Stark H: Multiple enzyme inhibitions by histamine $\mathrm{H}_{3}$ receptor antagonists as potential procognitive agents. Pharmazie 61:179-182, 2005.

Plaitakis A, Duvoisin RC: Homer's moly identified as Galanthus nivalis L.: Physiologic antidote to Stramonium poisoning. Clin. Neuropharmacol. 6:1-5, 1983.

Prast H, Fischer H, Prast M, Philippu A: In vivo modulation of histamine release by autoreceptors and muscarinic acetylcholine receptors in the rat anterior hypothalamus. Naunyn Schmiedebergs Arch. Pharmacol. 350: 599-604, 1994.

Prast H, Fischer H, Tran MH, Grass K, Lamberti C, Philippu A: Modulation of acetylcholine release in the ventral striatum by histamine receptors. Inflamm. Res. 46:37-38, 1997.

Proudfoot A: The early toxicology of Physiostigmine: A tale of beans, great men and egos. Toxicol. Rev. 25:99-138, 2006.

Rogawski MA, Wenk GL: The neuropharmacological basis for the use of memantine in the treatment of Alzheimer's disease. CNS Drug. Rev. 9:275-308, 2003.

Roth BL, Sheffler DJ, Kroeze WK: Magic shotguns versus magic bullets: Selectively non-selective drugs for mood disorders and schizophrenia. Drug Discov. Today 3:353-359, 2004.

Selbach O, Brown RE, Haas HL: Long-term increase of hippocampal excitability by histamine and cyclic AMP. Neuropharmacology 36:1539-1548, 1997.
Schlicker E, Betz R, Göthert M: Histamine $\mathrm{H}_{3}$ receptor-mediated inhibition of serotonin release in the rat brain cortex. Naunyn Schmiedebergs Arch. Pharmacol. 337:588590, 1988.

Schlicker E, Fink K, Detzner M, Gothert M: Histamine inhibits dopamine release in the mouse striatum via presynaptic $\mathrm{H}_{3}$ receptors. J. Neural. Transm. 93:1-10, 1993.

Schlicker E, Fink K, Hinterhaner M, Gothert M: Inhibition of noradrenaline release in the rat brain cortex via presynaptic $\mathrm{H}_{3}$ receptors. Naunyn Schmiedebergs Arch. Pharmacol. 340: 633-638, 1989.

Schlicker E, Werthwein S, Zentner J: Histamine $\mathrm{H}_{3}$ receptor-mediated inhibition of noradrenaline release in the human brain. Fundam. Clin. Pharmacol. 13:120-122, 1999.

Stark H: Recent advances in histamine $\mathrm{H}_{3} / \mathrm{H}_{4}$ receptor ligands. Expert Opin. Ther. Pat. 13: 851-865, 2004a.

Stark H: Turning from monogamy to strategic promiscuity. Drug Discov. Today 9:736-737, 2004b.

Sugimoto H, Ogura H, Arai Y, Iimura Y, Yamanishi: Research and development of Donepezil hydrochloride, a new type of acetylcholinesterase inhibitor. Jpn. J. Pharmacol. 89:7-20, 2002.

Summers WK: Tacrine, and Alzheimer's treatments. J. Alzheimers Dis. 9:439-445, 2006.

Tedford CE, Hoffmann M, Seyedi N, Maruyama R, Levi R, Yates SL, Ali SM, Phillips JG: High antagonist potency of GT-2227 and GT-2331, new histamine $\mathrm{H}_{3}$ receptor antagonists, in two functional models. Eur. J. Pharmacol. 351: 307-311, 1998.

Ting P, Aslanian R, Berlin MY, Boyce CW; Cao J; Mangiaracina P; Mc Cormick KD; Mutahi MW; Rosenblum SB; Shih NY; Solomon DM; Tom WC; Zeng Q: 1-(4Piperidinyl)benzimidazolones as histamine $\mathrm{H}_{3}$ antagonists. WO-03103669, 2003.

Tuomisto L, Tuomisto J: Diurnal variations in brain and pituitary histamine and histamine- $N$ methyltransferase in the rat and guinea pig. Med. Biol. 60:204-209, 1982.

Wada H, Inagaki N, Yamatodani A, Watanabe T: Is the histaminergic neuron system a regulatory center for whole-brain activity? Trends Neurosci. 14:415-418, 1991.

Wimo A, Winblad B, Aguero-Torres H, von Strauss $\mathrm{E}$ : The magnitude of dementia occurrence in the world. Alzheimer Dis. Assoc. Disord. 17:63-67, 2003.

Yang R, Hey JA, Aslanian R, Rizzo CA: Coordination of histamine $\mathrm{H}_{3}$ receptor antagonists with human adrenal cytochrome 
P450 enzymes. Pharmacology 66:128-135, 2002.

Yao BB, Hutchins CW, Carr TL, Cassar S, Masters JN, Bennani YL, Esbenshade TA, Hancock
AA: Molecular modeling and pharmacological analysis of species-related histamine $\mathrm{H}_{3}$ receptor heterogeneity. Neuropharmacology 44:773-786, 2003. 